DOI: $10.17516 / 1997-1370-0767$

УДК $390 ; 304.2$

\title{
Ethnocultural Dynamics of the Krasnoyarsk Territory in the Works of Krasnoyarsk Artists
}

\author{
Antonina I. Fil'koa, b Yulia N. Avdeevaa, \\ Anastasia V. Kistova, ${ }^{a, b}$ Natalia N. Pimenova ${ }^{a}$ \\ and Nina N. Robachevskaya*b \\ ${ }^{a}$ Siberian Federal University \\ Krasnoyarsk, Russian Federation \\ ${ }^{b}$ Krasnoyarsk Art Museum named after V.I. Surikova \\ Krasnoyarsk, Russian Federation
}

Received 25.03.2021, received in revised form 15.04.2021, accepted 24.05.2021

\begin{abstract}
The article analyzes the originality of the ethnocultural dynamics of the Krasnoyarsk Territory in the context of artistic practice. The general dynamics of ethnic groups inhabiting the Krasnoyarsk Krai from the early $17^{\text {th }}$ century to the early $21^{\text {st }}$ century is shown. At the same time, within the framework of this dynamics such stages pre-Soviet, Soviet and post-Soviet were identified. A general characteristic of the creativity of Krasnoyarsk artists who worked in the selected periods is given. Within the framework of the philosophical and art history analysis, the works of D. I. Karatanova, Yu.P. Ishkhanov and S. E. Anufrieva as the most representative for each period and, at the same time, allowing to consider creativity in its various forms (painting, sculpture and ceramics) were selected and studied in detail. As a result, it was concluded that these works most clearly reflect the changes of a person living in these territories and his/her relationship with nature and historical roots.
\end{abstract}

Keywords: ethnocultural dynamics, Krasnoyarsk Krai, Krasnoyarsk artists, philosophical and art history analysis.

The reported study was funded by RFBR, project number 19-311-90015.

Research areas: culturology, art history.

Citation: Fil'ko, A.I., Avdeeva, Yu.N., Kistova, A.V., Pimenova, N.N., Robachevskaya, N.N. (2021).

Ethnocultural dynamics of the Krasnoyarsk Territory in the works of Krasnoyarsk artists. J. Sib. Fed. Univ. Humanit. Soc. Sci., 14(6), 873-889. DOI: 10.17516/1997-1370-0767.

\footnotetext{
(c) Siberian Federal University. All rights reserved

* Corresponding author E-mail address: avdeeva2406@mail.ru, kistochka7@mail.ru, pimenovapluzhnik@mail.ru, nisla@mail.ru, chalkywolf@gmail.com, nisla@mail.ru

ORCID: 0000-0002-5309-4616 (Kistova); 0000-0002-2787-423X (Fil'ko); 0000-0002-0622-4465 (Pimenova)
} 


\title{
Этнокультурная динамика Красноярского края в творчестве красноярских художников
}

\author{
А.И. Филько ${ }^{\text {a, }}$, Ю.Н. Авдеева ${ }^{a}$ А.В. Кистова ${ }^{a, 6}$, \\ Н.Н. Пименова , Н.Н. Робачевскаяб \\ ${ }^{a}$ Сибирский федеральный университет \\ Российская Федерачия, Красноярск \\ ${ }^{\sigma}$ Красноярский художественный музей имени В.И. Сурикова \\ Российская Федерация, Красноярск
}

\begin{abstract}
Аннотация. Проводится анализ своеобразия этнокультурной динамики Красноярского края на примере художественной практики. Показана общая динамика этносов, населяющих территории Красноярского края с начала XVII до начала XXI века. При этом в рамках данной динамики были выделены следующие этапы: досоветский, советский и постсоветский. Дана общая характеристика творчества красноярских художников, творивших в названные периоды. В рамках философско-искусствоведческого анализа были отобраны и подробно рассмотрены произведения Д.И. Каратанова, Ю.П. Ишханова и С.Е. Ануфриева как наиболее репрезентативные по каждому периоду и при этом позволяющие изучить творчество в разных его формах (живописи, скульптуре и керамике). В результате были сделаны выводы о том, что эти произведения наиболее явно отображают изменения человека, живущего на данных территориях, и его взаимоотношения с природой и историческими корнями.
\end{abstract}

Ключевые слова: этнокультурная динамика, Красноярский край, красноярские художники, философско-искусствоведческий анализ.

Исследование выполнено при финансовой поддержке РФФИ в рамках научного проекта № 19-39-90015.

Научные специальности: 24.00.00 - культурология, 17.00.00 - искусствоведение.

\section{Введение}

Проблемы этнокультурной динамики имеют длительную историю в области социально-исторических знаний. Для Красноярского края эта тема значима, поскольку на территории края проживает более 150 этносов, каждый из которых имеет свою историю и развитие. Исследование динамики культурных изменений этносов является приоритетной задачей для понимания единого вектора развития народов, населяющих данную территорию.

\section{Методы и материалы}

В качестве методологии исследованием используются теоретические положения современной теории изо- бразительного искусства В.И. Жуковского (2011) и Н.П. Копцевой (2014), а ведущим методом выступил философскоискусствоведческий анализ, эффективность применения которого доказана целым массивом исследовательских работ, среди которых также научные публикации Е.А. Сертаковой (2014), К.В. Резниковой (2014), А. А. Ситниковой (2014), Н.Н. Середкиной $(2011,2019)$ и др. (Kistova, et al., 2020). Данный метод был неоднократно апробирован для анализа этнокультурной проблематики на материале анализа художественной культуры Красноярского края и других регионов мира (см. Koptseva, Reznikova, Razumovskaya, 2018; Amosova, et al., 2019; Reznikova, et al., 2017, и др.). 
Материалами исследования выступили произведения красноярских художников, ярко визуализирующие этнокультурную динамику Красноярского края и репрезентирующие три ее ключевых этапа: досоветский, советский и постсоветский (современный) периоды. Ключевыми критериями отбора произведений для анализа стали репрезентативность творчества художников и их конкретных творений по отношению к каждому из этапов, а также соответствие их историческим границам периодов. Для анализа выбраны произведения коллекции Красноярского художественного музея имени В.И. Сурикова: картина Д.И. Каратанова «Тайга (Столбы)» (1934-35?), скульптура Ю.П. Ишханова «Портрет начальника строительства Красноярской ГЭС А.Е. Бочкина» (1968), Произведение С.Е. Ануфриева «Композиция из трех частей «Три шамана» (1989).

\section{Своеобразие этнокультурной динамики Красноярского края}

Этнокультурную динамику Красноярского края отличают существенные изменения состава населения на протяжении истории этой большой территории и смена этнодоминант. Красноярский край в данный момент представляет собой объединенный регион, в 2007 году включивший в себя Эвенкийский и Таймырский (Долгано-Ненецкий) АО, которые в составе края получили статус муниципальных районов. Национальное многообразие населения края, характерное для сегодняшнего времени, складывалось постепенно.

До XVI века на территории Приенисейской Сибири проживали преимущественно индигенные для Красноярского края народы. Освоение енисейских земель первыми казачьими отрядами, которые составили выходцы из Центральной части России, Поволжья и Приуралья, пришлось на конец XVI - начало XVII века. Интенсивность этнокультурной динамики XVII века привела к тому, что к началу XVIII века коренные народы утратили свое доминантное положение, поскольку по численности явно уступали представителей других земель и этносов.
Еще один этап этнокультурной динамики Красноярского края досоветского времени отмечен действием аграрной реформы П.А. Столыпина и строительством Транссибирской железной дороги. Известно, что за один только 1908 год по железной дороге в Сибирь было перевезено более 750 тысяч переселенцев самых разных национальностей. В послереволюционное советское время причиной существенного притока населения стала высылка военнопленных и приезд беженцев из-за голода по причине неурожая в Поволжье в начале 1920-х годов, а также ссыльнопоселенцев (1930-1940-е годы). Позднее многие из ссыльных и беженцев покинули территорию края, вернувшись на родину, но оставшиеся на постоянное поселение существенно изменили этносостав Красноярского края - произошел как приток в существующие этногруппы (диаспоры), так и образование ранее не свойственных диаспор (например, греки, калмыки, корейцы, китайцы и др.) (Enciklopediia Krasnoiarskogo kraia, 2021). В это же время происходит выделение коренного населения Красноярского края в особую группу народов. Еще в 1920-х годах в России группа населения, проживающая в особо трудных климатических условиях, отличающаяся малой численностью и ведущая традиционный образ жизни, была выделена среди других национальностей и именована коренными малочисленными народами (Mamysheva, 2018; Tuguzhekova, 2017). В документе 1925 года «О положении национальных меньшинств в Енисейской губернии» они определяются как «национальные меньшинства», «нацмен население». Также в нем отмечено, что на тот момент в Туруханском крае проживали 13000 «северных туземцев», а остальные 160000 представителей коренных народов были расселены по всей территории отдельными селениями, и большинство из них приходится на Красноярский уезд (Etnicheskaia istoriia narodov Krasnoiarskogo kraia ..., 2006).

Во второй половине XX века прослеживается новая картина этнокультурной динамики Красноярского края. Отмечается, что 
в 1950-е годы в крае появляются крупные диаспоры грузин, армян, азербайджанцев, приехавших на имеющиеся в крае рабочие места, в 1960-е годы - узбеков и молдаван. В 1976-1980 годах происходит значительное промышленное развитие Красноярского края: на территории региона действовали 10 Всесоюзных комсомольских строек. На этих стройках работали более 30 тысяч приезжих, в результате в крае формируются крупные группы киргизов, осетин, таджиков, чеченцев, ингушей, народов Дагестана (лезгин, аварцев, кумыков, даргинцев).

1990-е годы отмечены иной динамикой: сокращением численности некоторых длительно существующих диаспор. Стоит отметить, что при этом в целом этнический состав населения Красноярского края в постсоветское время, начиная с 1990-х годов, значительно расширяется (Lysenko, 2008). Отмечается появление таких этногрупп, как езиды, талыши, нагайбаки, русины, бесермяны, кереки, кумандинцы, телеуты, чулымцы. Сегодня коренные малочисленные народы проживают на северозападе Красноярского края - в Тюхтетском районе (чулымцы), и в северных его территориях: Эвенкийском муниципальном районе, Туруханском районе, Таймырском Долгано-Ненецком муниципальном районе, Туруханском районе, а также в некоторых поселениях Енисейского и СевероЕнисейского районов (Oficial'nyj portal Krasnoiarskogo kraia, 2021). Согласно данным официальной статистики, в объединенном Красноярском крае исконное население сегодня представляют 10 из 26 сибирских этносов, 9 из них имеют статус малочисленных. Как позволяет заключить история этнокультурной динамики, весьма обширен и список коренных сибирских народов, проживающих в крае, но не имеющих здесь исконных территорий, и список народов из несибирских регионов, входящих или некогда входивших в состав страны (СССР, РФ).

Описанные выше изменения этнокультурной картины Красноярского края нашли свое воплощение в художественной практике, традиционно рефлексирующей социальные изменения посредством визуализации характерных черт общества своего времени.

\section{Обзор художественной практики \\ Красноярского края}

как визуализации этнокультурной динамики

Произведения изобразительного искусства наряду с другими источниками, отражающими культурное наследие, обладают высокой социокультурной значимостью и представляют собой инструмент сохранения и воспроизводства культуры народов Красноярского края. Кроме того, произведения изобразительного искусства, освещающие быт этнокультурных сообществ, традиционные способы хозяйствования и иные практики освоения мира, моральные и религиозные традиции и менталитет, выступают средством конструирования этнокультурной идентичности.

Для первой половины XIX - начала XX века характерно этнографическое и документальное направление в творчестве красноярских мастеров. Это период, когда художники участвовали в научноисследовательских экспедициях и фиксировали подробности северной жизни, быта. Художественные задачи как таковые смещались на второй план.

Тема этнокультурной динамики впервые затрагивается в работах известнейшего художника В.И. Сурикова, прославившегося в жанре исторической живописи. В рамках тематики данной статьи уместнее всего будет указать на его работы «Покорение Сибири Ермаком Тимофеевичем» (1895 г.) и «Взятие снежного городка» (1891 г.).

Одним из первых красноярских художников советского периода, обратившихся в своем творчестве к теме народов Красноярского края, стал Д.И. Каратанов. В своих произведениях Каратанов уделял особое внимание северным пейзажам и быту. Большинство его работ выполнены графически и представляют собой эскизы и карандашные зарисовки. В его работах можно найти очень точное изображение рыболовных снастей, традиционных лодок, способов приготовления рыбы и изображения самих 
народов. Наиболее ранние работы были выполнены в результате поездки на Север в 1906 г. - это были портреты, выполненные маслом: «Остяк в чуме» и «Шаманка». Среди графических работ Каратанова стоит отметить следующие: «Сибирский дворик» (1920 г.), «Кеты-рыбаки» (1928 г.), «Оленьи юрты» (1928 г.), «Тюки, Сети, Лодки» (1928 г.), «Экспедиция Нансена (1936 г.), «Охотники» (1948 г.).

Еще один выдающийся красноярский художник, ученик Д.И. Каратанова А.П. Лекаренко, в период своей творческой деятельности осуществлял многочисленные поездки по Красноярскому краю и другим регионам Сибири. Результатом этих перемещений становятся многочисленные работы, посвященные этнокультурным сообществам. Его работы отличаются изображением самих коренных народов, своеобразия северного колорита, созданием обобщенного образа народов с четкой прорисовкой деталей одежды и быта: «Малица авамских самоедов» (1927 г.), «Пастухи-оленеводы с Таймыра» (1957 г.), «Девушка с Таймыра» (1959 г.). Особый интерес представляют натурные зарисовки северян: «Нганасан Мунто», «Нганасан Сундампте», «Силкин ненец», «Нганасан Ептудуси», «Нганасан в сакуе», «Мальчик-ненец Семен».

Образы северной и сибирской природы можно наблюдать в пейзажном творчестве Б.Я. Ряузова. В 1950-е годы он предпринял поездку в Туруханск, в результате которой создал «Туруханскую серию» (1949-1951 гг.) из восьми пейзажей. В 1970-е. годы он отправился в Заполярье и презентовал картины на северную тематику на академической выставке 1976 года. Ряузов был художником военного и послевоенного периодов, в его работах запечатлены драматические моменты войны, где его интересовали вопросы колорита и соотношения цветов. В своих работах он решает проблему соотношения небесного и земного колорита, обращая внимание на вторжение разноцветья речных подъемных кранов и кораблей в портах в северную монотонность. Среди работ Ряузова сто- ит выделить «Старый Туруханск в устье Нижней Тунгуски» (1951г.), «В затоне» (1973 г.), «Улица в старом Красноярске» (1981 г.), «Север. Заполярье» (1987 г.). Кроме того, нельзя не отметить серию картин «Исторические места Сибири, связанные с жизнью и деятельностью В.И. Ленина»: «Дом, где жил В. И. Ленин», «Шушенское. Окно В.И. Ульянова», «Енисей. Шторм стихает», «Шушенские просторы», «Енисей перед снегопадом».

Обращение к тематике этнических культур получило формат «новой волны» со второй половины XX в. Теперь уже, отправляясь на Север, художники решают и художественные задачи - композиционные, цветовые, сюжетные, философские. Создают образы в эстетике «сурового стиля», отражают эпические достоинства северной природы. Кроме того, происходит жанровое расширение: основой для конструирования новых художественных образов выступают представители коренных этнокультурных групп, их человеческие качества, а также животные. Среди художников этого периода стоит назвать Г.Г. Горенского, А.А. Довнара и В.Ф. Капелько, В.И. Мешкова, Т.В. Ряннеля, Ю.Д. Деева, В. Б. Рослякова, Г. Мусина, Н.И. Рыбакова, В. А. Сергина, Ю. Ишханова и др.

Г.Г. Горенский еще со студенческих лет посвятил свое творчество природе Сибири, ездил в тундру, путешествовал по тувинским и хакасским степям, по Саянам. Его мастерство раскрывается в картинах «Новая одежда» (1969 г.), «Рыбаки-ненцы» (1972 г.), «На озере Хантайском» (1986 г.), «Такмак» (1989 г.), «Первый снег» (2000 г.).

А.А. Довнар тоже много путешествовал по Северу, его любимой деревней была д. Самково. Большинство его работ выполнено в жанре пейзажа и натюрморта. Ocoбенность творчества Довнара в том, что он расширяет границы северных изображений, дополняя их образами животных («В горах Путорана», 1978 г., «Мой друг - Учум», 1988 г.). Предметам быта северных народов художник дает новую жизнь и как бы рассказывает их историю («Нганасанские трубки», 1973 г.). 
Одним из наиболее самобытных красноярских художников послевоенного времени является В.Ф. Капелько. Он, как и многие другие художники, искал вдохновения в путешествиях. Капелько своем творчестве интересовался прежде всего не этнографическими деталями, а световыми эффектами: полярные ночи и дни, северное сияние, высокая степень солнечного освещения, усиливающаяся снежными покровами. Среди основных работ можно выделить следующие: «Отец с сыном у чума» (1962 г.), «В устье реки Чинге» (1977г.), «Эстампажные копии петроглифов г. Куня, с. Усть-Абакан», «Курган» (1983 г.).

Еще одним известным художником, мастером линогравюры, является В.И. Мешков. В партийные времена он был направлен на работу в Эвенкию как раз в тот период, когда эвенкийское население практически не говорило на русском языке, поэтому основу его творчества и составляла графика, которая была понятна любому человеку без слов. Это цветные линогравюры «Поздний гость, «На факторию», «В верховьях Кочечумо», «К далекому другу», «В охотничьей бригаде», «Олени в море», «В Туре» и многие другие.

Красноярский живописец Т.В. Ряннель отличался тем, что стремился в своем творчестве представить наиболее эпичные, относящиеся к основаниям, фундаментальные образы Красноярского края. Ему принадлежат такие полотна, как «Рождение Енисея» (1958 г.), «Горные кедры» (1959 г.), «Фактория на Подкаменной Тунгуске» (1963 г.).

Советский художник Ю.Д. Деев является художником яркого образного стиля, где сибирская деревня окрашена особым фольклорным началом и ироничной философией. Он осуществил большую поездку по сибирским селам, за которой последовал цикл работ, где он изображал жизнь простых людей в сибирской глубинке: «Суббота. Банный день» (1992 г.), «Мыслитель» (1995 г.), «Дед ушел от бабки» (1996 г.) и др.

$$
\text { Среди самобытных художников }
$$
Красноярского края нельзя не упомянуть о В.Б. Рослякове, для творчества которого характерна ностальгическая трактовка северных сюжетов. Его картины пронизаны любовью к северным народам, на них можно увидеть образы большой души этих людей («Воспоминание о Севере», 1984 г., «Северные просторы», 1988 г., «У рыбзавода», 1989 г.).

В начале XXI столетия наблюдается снижение интереса красноярских художников к этнокультурной тематике. Можно предположить, что это обусловлено «перетягиванием» функции документирования жизни этносов фотографией. Кроме того, в среде коренных народов появляются собственные профессиональные художники, прекрасно визуализирующие специфику этнической культуры в произведениях изобразительного искусства самостоятельно.

Однако некоторые красноярские художники продолжают успешно раскрывать философию Севера, проводить параллели между северной и другими культурами. Север на полотнах К.С. Войнова - это обращение, прежде всего, к людям, которые его населяют, в них отсутствует любование пейзажами. Между тем для его картин характерны яркие цветовые эффекты и движение облаков, наводящие на размышления космических масштабов. Его картины не столько жизнеописательны, сколько имеют символический смысл. Среди множества его работ уместнее всего будет отметить цикл картин «Этника Сибири», включающий более 20 живописных произведений, выполненных в период с 2008 по 2016 год.

Известен в Сибирском регионе и за его пределами художник декоративноприкладного искусства, основоположник уникального художественного явления под названием этно- или неоархаики С.Е. Ануфриев. Для его декоративных композиций характерно глубокое осмысление семантики древних культур («Сибирская композиция», 1991, «Три шамана»).

К самобытным художникам начала XXI века, работающим в самых разных художественных стилях, использующим самые разные техники и материалы, можно отнести А.И. Волокитина, Г.С. Паштова, Г.И. Гуркина, Д. Б. Намдакова, З. Б. Дор- 
жиева, Б. Сундупова, П.А. Гармаева, Х.К. Тойбухаа, Д.Х. Дойбухаа, Ш. Чурук, Л. М. Норбу, Б. Дамбиева и др.

\section{Картина Д. И. Каратанова}

«Тайга (Столбы)» (1934-35?)

Значение творческой и педагогической деятельности заслуженного деятеля искусств РСФСР Дмитрия Иннокентьевича Каратанова (1874-1952) для красноярской художественной школы трудно переоценить (Riannel', 1948; Chirkov, 2018; Stroj, 2017).

Будучи лично знакомым с В.И. Суриковым, Дмитрий Иннокентьевич строил свой творческий путь, опираясь на основные принципы творчества великого земляка. Так, главной в его творчестве стала тема Сибири, сибирской земли и сибирских людей, населяющих эту землю с давних времен и живущих на ней сейчас. Суриков обращался к этой теме через исторический сюжет, как это видно в его эпическом полотне «Покорение Сибири Ермаком» (1891-95). Интересно, что не только образы воинов хана Кучума, но и образы казаков для картины были найдены Суриковым на родине, в Сибири: «Только некоторых казаков я писал не в Сибири, а на Дону, где мне не трудно было их подыскать» (Vasilij Ivanovich Surikov. Pis'ma, 1977).

В картине встреча казачьей дружины Ермака и войска сибирского хана Кучума в 1582 году показана как встреча двух стихий, двух культур, двух разных времен. Войско хана Кучума заполняет прибрежное пространство и высокий берег, сливаясь с землей и словно являясь ее продолжением. Дружина Ермака изображена более крупно, на низких лодках прибывающей к берегу. Два войска разделяет только дым от пороховых ружей, которые использовали казаки. Суриков выстраивает взаимодействие этих двух масс так, что они, с одной стороны, противопоставлены друг другу, с другой - похожи друг на друга тем, что изображены в схожих состояниях и в схожих цветах. Это цвета природного пространства, в котором разворачивается это эпическое событие. Та- ким образом, В.И. Суриков представляет не только динамику смены доминирующего этноса и культуры на территории Сибири в XVI-XVII веках, но и характерную особенность этой динамики - соответствие побеждающей силы/культуры/ этноса характеру сибирской земли. Именно эту линию продолжает в своем творчестве Д.И. Каратанов, обращаясь к жанру пейзажа.

Картина «Тайга (Столбы)» (холст, масло, 99х69 см) (рис. 1) является характерной в пейзажном творчестве Дмитрия Иннокентьевича. Средний размер произведения настраивает на более доверительное общение зрителя с произведением, которое представляет мир сибирской природы как будто через небольшое окно. Эта картина предполагает внимательное всматривание в детали и общий образ.

Композиционно полотно можно разделить на три плана по горизонтали.

Первый план - нижнее пространство картины с преобладанием охристых оттенков, множеством светлых пятен в левой части и темными пятнами в правой представляет изображение таежной земли, недавно оттаявшей и вновь покрытой весенним снегом. Можно сказать, что это пространство наиболее теплое и близкое к зрителю и одновременно наиболее разнообразное. Особенно выделяются два диагональных ствола дерева в левой части, силуэт маленькой елочки чуть левее центральной вертикали и темные пятна более взрослых елей в правом углу.

Второй план - широкое среднее пространство, в котором преобладает темный фон и тонкие вертикальные светло-серые формы - это изображение молодого, но уже непроглядного таежного леса, состоящего из тонких стволов осин, берез и елей. Эта зона самая крупная и притягивающая к себе внимание. В ней собираются темные оттенки цвета и тона, концентрируясь слева от центральной вертикали полотна. Все пространство пронизывают светло-серые вертикали стволов осин, образуя равномерную ритмическую решетку произведения. Особенно выделяются четыре вертикаль- 


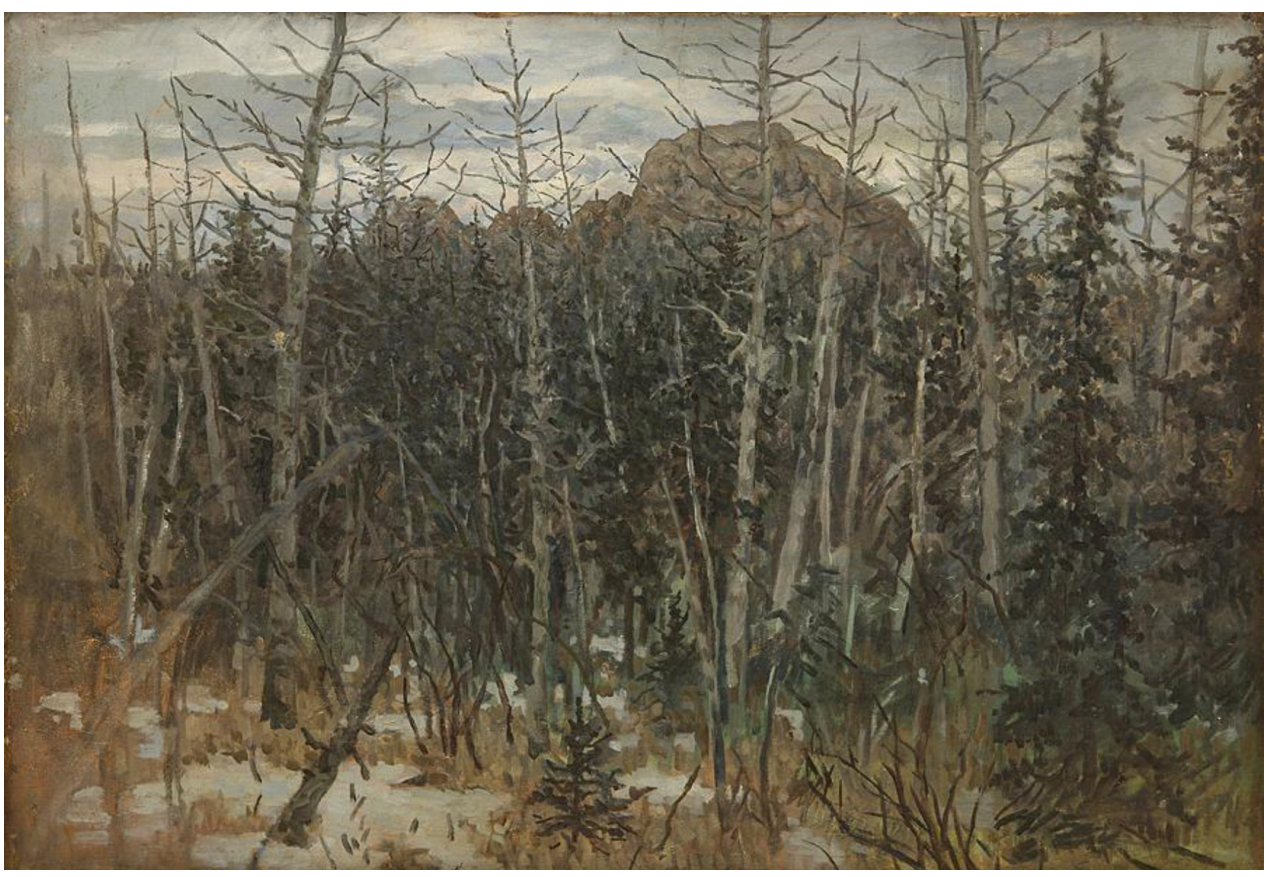

Рис. 1. Каратанов Д.И. Тайга (Столбы). 1934-35(?).

Красноярский художественный музей имени В.И. Сурикова

Fig. 1. Karatanov D. Taiga (Stolby). 1934-35(?). Krasnoyarsk Art Museum named after V. Surikov

ных ствола с примерно равными расстояниями между ними.

Третий план - самый верхний и светлый - изображение пасмурного неба с проглядывающим сквозь облака солнышком и пересекающими все пространство по вертикали верхушками голых молодых осин. Именно в этой части виден силуэт вершин красноярских Столбов, выделенных контрастным соотношением со светлым фоном неба.

Объединяющим элементом для всех трех планов является изображение деревьев. Общий равномерный ритм, задаваемый стволами молодых осин, поддерживается силуэтами елей в правой части произведения и акцентами в нижней полосе. В этом равномерном ритме есть акценты. Это наиболее темная зона в средней полосе изображения и вершина Столбов в верхней части картины. В соединении с диагональными стволами заваливающихся деревьев в нижней части изображения эти акценты выстраиваются в ясную диагональ, собираю- щую все три плана картины. Эта диагональ собирает контрастные символы: покосившиеся стволы погибающих деревьев среди снежных тающих островков, непроглядная лесная чаща, вершина скал на фоне пасмурного весеннего неба. Это знаки, говорящие о бренности и недолговечности жизни, с одной стороны, о вечном обновлении и росте - с другой. Обе стороны составляют вечный ритм природного цикла.

Интересна в этом процессе роль мотива маленькой елочки, изображение которой может стать для зрителя проводником в мир таежной глуши. Хрупкий силуэт возникает в пространстве, наиболее близком пространству зрителя, рядом с центральной вертикалью картины. Затем этот силуэт повторяется чуть выше, на границе перехода из нижней полосы в центральную. Далее уже более размыто силуэты елей прочитываются в центральной полосе. И во всей красе изображение тонких и стройных еловых деревьев представлено в правой части произведения. Мотив ели в произведении 
предлагает зрителю возможный образец для подражания: расти не одиноко в стороне ото всех, но и не сливаясь с общей толпой, тянуться вверх сквозь все преграды, не теряя своего облика, не сворачивая с избранного пути и приобретая в итоге свой узнаваемый и уникальный облик. Этот мотив поддерживает и образ самих Столбов. Скалы как символ вечного стремления к небу, незыблемости и основательности усиливают диктатный характер изображенного в произведении природного ритма, превращая его в закон мироздания.

Таким образом, в произведении Д.И. Каратанова «Тайга (Столбы)» чувственно явлена сущность местного природного колорита, предлагаемая зрителям в качестве образца для подражания. Здесь (на сибирской земле) важны черты характеpa, a не этнические, религиозные или культурные признаки.

Эта тема, тема связи человека и природы, красной нитью пройдет и через творче- ство советских художников Красноярского края, но ее осмысление будет отвечать уже реалиям и требованиям советского времени.

\section{Скульптурное произведение}

\section{Ю. П. Ишханова «Портрет начальника} строительства Красноярской ГЭС

\section{А.Е. Бочкина»}

Одним из ключевых жанров советского периода в искусстве Красноярского края является жанр портрета. Наиболее ярко это проявилось в творчестве Юрия Павловича Ишханова (1929-2009).

Станковый скульптурный «Портрет начальника строительства Красноярской ГЭС А.Е. Бочкина» (рис. 2) выполнен автором в 1968 году из бронзы. Для создания портретного образа скульптор лично познакомился с А.Е. Бочкиным (1906-1979), который к началу 1960-х годов стал начальником строительства Красноярской

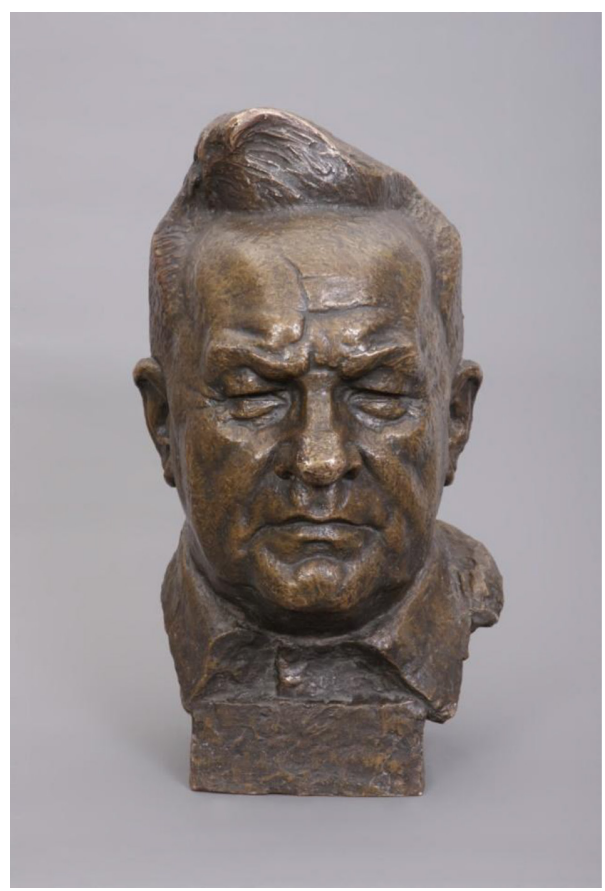

Рис. 2. Ишханов Ю.П. Портрет начальника строительства Красноярской ГЭС А.Е. Бочкина. 1968. Красноярский художественный музей имени В.И. Сурикова

Fig. 2. Ishkhanov Yu. Portrait of site manager A. Bochkin. 1968. Krasnoyarsk Art Museum named after V. Surikov 
ГЭС и переехал трудиться и жить в г. Дивногорск.

Исследователи творчества мастера утверждают, что Ю.П. Ишханов был необычно внимательным человеком, скульптор предпочитал лепить с натуры, пропуская образ портретируемого через призму собственного взгляда (Moskaliuk, Znak, Rakova, 2000; Lomanova, 2007; Shavlygin, 2020; Moskaliuk, 2010).

Композиционно образ решен в виде портретной головы, поставленной шеей с глухо застегнутым воротником на квадратную в сечении, устойчивую подставку. Вся композиция отлита единой монолитной формой и скомпонована автором на строго фронтальный обзор. Это может говорить о том, что мастеру было важно привлечь внимание зрителя именно к лицу портретируемого, его чертам и строению.

Перед зрителем явлен умудренный опытом и годами мужчина, его лицо имеет правильные, симметричные черты: высокий, выпуклый лоб разрезан значительным и достаточно широким вертикальным шрамом, нарушающим симметрию лица, идущим к правой части переносицы и брови портретируемого; переносица напряжена, о чем свидетельствуют глубокие горизонтальная и вертикальная складки, брови сведены и опушены; глаза несколько прикрыты, но веер тонких морщинок в их углах говорит о том, что глаза скорее прищурены, нежели закрыты, а взгляд обращен внутрь; возле крыльев ровного носа можно увидеть глубокие носогубные складки, говорящие о том, что человек много улыбается; губы сомкнуты, но не сжаты, скорее они зафиксированы в скупой мужской «полуулыбке»; волевой подбородок расслаблен. Весь образ начальника строительства Красноярской ГЭС демонстрирует устойчивость, собранность, сосредоточенность и аккуратность. Голова портретируемого выглядит и ощущается необычайно монументально.

На материальном статусе «Портрета начальника строительства Красноярской ГЭС А.Е. Бочкина» формируется композиция, построенная на принципе преобладающей устойчивости, монументальности, ясности, но также фиксируется противопоставление симметрии и асимметрии в скульптурном образе.

Архитектоника скульптурного образа А.Е. Бочкина дает ощущение монолитности и устойчивости, перед зрителем явлен лик человека-глыбы, человека, формирующего реальность с помощью мысли и дела, человека, чей путь не был легким, но трудности не сломили, а, наоборот, сформировали и закалили его. Несмотря на статичность фигуры, мастер через подчеркнутую с помощью работы света и тени асимметрию в деталях задает возможность существования внутри образа скрытого движения. Это движение куда более энергичное и мощное, чем движение явленное, - это сила бурлящей мысли и воли портретируемого, именно поэтому скульптор уделяет особое место в лепке зоны переносицы и лба начальника строительства Красноярской ГЭС. Такого напряженного места по количеству складок и фактур нет ни в одной точке портрета. Портретируемый будто бы силой мысленного сосредоточения старается удержать какое-то внутреннее движение, энергию.

Обращаясь к натуре, скульптор не мог уйти от индивидуальных портретных черт модели, но он не свойственно для А.Е. Бочкина «приподнимает» волосы и «укладывает» их волной надо лбом, открывая зрителю примечательный шрам. Из-за этого образ начальника строительства Красноярской ГЭС зритель начинает воспринимать не как портрет конкретного человека, но как символ места и события. Ясный и глубокий шрам на лбу асимметрично делит его на правую и левую части, рубец, будто русло реки, разрезает лик Сибирской земли. Улавливая портретное сходство с натурой, автор подчеркивает асимметрию, которая вторит очертаниям бассейна реки Енисей. А «вздыбленная прядь волос на голове явно отождествляется с могучей волной Енисея» (Shavlygin, 2020). Художественный образ скульптурного портрета словно «лик гидрологической карты» Красноярского края с главной его водной артерией - Енисеем, чья природная мощь силой человеческой 
мысли была преобразована в электроэнергию.

Таким образом, в скульптурном протрете А.Е. Бочкина, с одной стороны, явлен образ нового советского человека мудрого, могучего гиганта, способного покорять природные стихии, с другой стороны, это произведение выступает продолжением темы единения сибирского человека и сибирской природы, но в новом ключе: человек пытается дорасти до мощи природы и освоить ее силой разума, уподобляясь ей даже физически. Важно отметить, что этические и культурные признаки в данном случае носят второстепенный характер, уступая первенство базовым чертам характера человека-глыбы, такого же могучего, как та земля, на которой он живет и мощь которой осваивает.

\section{Произведение С.Е. Ануфриева «Композиция из трех частей «Три шамана» (1989)}

Творчество С. Е. Ануфриева посвящено переосмыслению древних культур (род. 1960). Пространственная трехчастная композиция «Три шамана» (рис. 3) выполнена автором в 1989 году и может быть отнесена к постсоветскому периоду в красноярском искусстве, поскольку в ней проявлены характерные тенденции этого времени. Во-первых, именно в конце $\mathrm{XX}$ века наметился интерес красноярских авторов к теме древних культур и народов, некогда населявших данную территорию. Во-вторых, наиболее ярко этот процесс стал происходить именно среди мастеров красноярской школы керамики. В-тре-

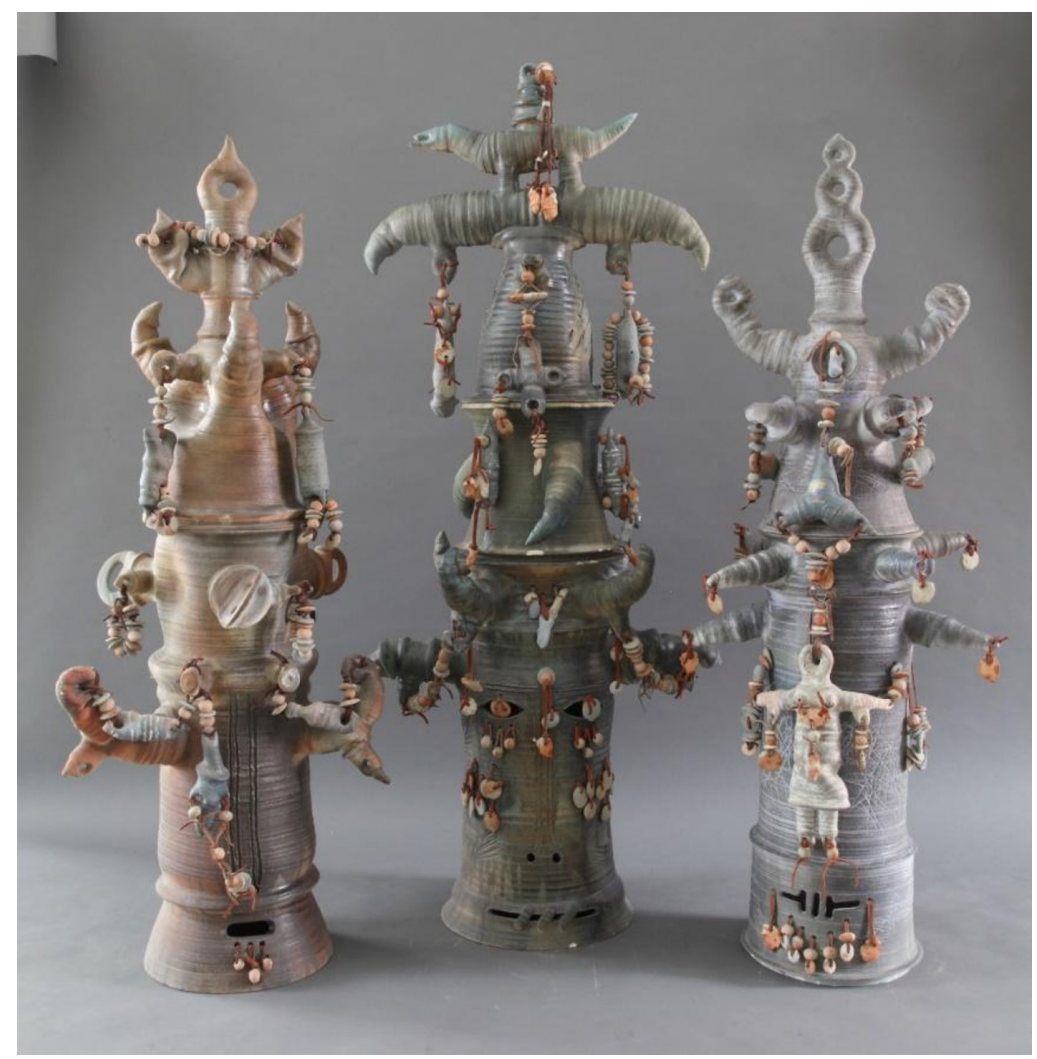

Рис. 3. Ануфриев С. Е. Композиция из трех частей «Три шамана». 1989. Красноярский художественный музей имени В.И. Сурикова

Fig. 3. Anufriev S. Three shamans. Ornamental design of three parts. 1989. Krasnoyarsk Art Museum named after V. Surikov 
тьих, обращение к этноархаике в постсоветский период стало носить декоративносимволический характер, что явно видно в рассматриваемом произведении.

Автор создает композицию из глины с применением солей, ангоб и декорирует работу кожаными шнурами. Он работает, совмещая гончарную технику с ручной лепкой. Высота боковых элементов 150 см, центрального - 160 см.

Для создания данной композиции Сергей Евгеньевич Ануфриев изучил огромное количество художественного и этнографического материала древних культур Сибири (Южной и Северной), Хакасии, Алтая, Монголии, Тувы, народов Нижнего Амура и Тропической Африки (Chirkov, 2010; Khudonogova, 2001; Maloletkov, 2004; Lomanova, 2015; Trigaleva).

Автор избегает искусственных анилиновых красок в декорировании форм, отдавая предпочтение натуральным пигментам естественного зеленого и серо-охристого оттенков, поэтому «Три шамана» выглядят как продолжение или порождение самой природы.

Объемы «Трех шаманов», круглые в сечении, состоят из нескольких частей, поставленных вертикально друг на друга (боковые элементы двухсоставные, центральный объект - трехсоставной). Это, с одной стороны, диктуется самим материалом и техническими возможностями обжига, а с другой - подчеркивает пирамидальность керамической композиции. Несмотря на то, что боковые части «Трех шаманов» физически состоят из двух объемов, автор каждый вертикальный объект композиционно делит на три части (нижнюю, среднюю и верхнюю), чему способствуют явные горизонтальные желоба на теле всех трех декоративных скульптур. Создавая многофигурную керамическую композицию, С.Е. Ануфриев использует обилие криволинейных элементов, антропоморфные, геометрические, растительные и фаллические мотивы, что умозрительно отсылает зрителя к артефактам древних культур.

На материальном статусе произведения «Три шамана» задается композицион- ный принцип, влияющий на дальнейшее развитие художественного образа. Это иерархическая, замкнутая (круглая в сечении) трехчастная система, построенная по пирамидальному принципу.

Архитектоника и сопряженность частей композиции позволяют говорить о содержании скрытых смыслов, выраженных через форму. Так, начиная «послойно» изучать объемы «Трех шаманов» снизу вверх, мы видим, что нижняя и самая крупная часть у всех трех декоративных скульптурэто стилизованные изображения масок. Центральный объем демонстрирует «зашитую» прорезь рта, округлые отверстия для носа, миндалевидные прорези глаз с декоративными, «навешенными» на кожаные шнуры, разноцветными зрачками. Нижняя часть боковых объемов композиции также демонстрирует образы масок, но уже более формально: видны лишь прорези для рта, «лицо» масок закрыто декоративными округлыми и условно-природными элементами из глины и кожаного шнура, а также антропоморфной фигуркой куклы-оберега панё (Smoliak, 1969). Средняя и верхняя части всех трех объемов композиции пропорционально меньше в диаметре и являют собой богато декорированные керамические отростки, продолжающие мотив нижней части композиции и напоминающие по форме рога или фаллические символы, направленные в разные стороны. Боковые формы венчают трезубцы с округлыми отверстиями, направленными вверх, средняя часть композиции в верхней части имеет условное изображение животного или рептилии (дракона), на спине которого расположена трехуровневая пирамида с округлым отверстием и декорированием на кожаном шнуре.

Все три части композиции «Три шамана» подчиняются общему пирамидальному принципу построения от более крупных форм к мелким, снизу вверх. Форма каждой части композиции условно напоминает ствол дерева с ветвями или столб, декорированный антропоморфными изображениями и природными (фаллическими) элементами, одновременно изображая древний 
лик (маску) с высоким причудливым головным убором.

Такие богато декорированные, причудливых форм и закрывающие лицо головные уборы (часто идущие в комплекте с масками) встречаются у шаманов. Как подчеркивают ряд авторов, изучающих творчество мастера, С.Е. Ануфриев тщательно подбирает названия своим произведениям, поскольку его работы никогда не являются «просто формой», но всегда неким посланием к зрителю (Chirkov, 2010). «Маски, как атрибут практически всех древних культов, сохраняя связь с архетипическими прообразами, приобретают в творчестве Ануфриева исключительное звучание» (Trigaleva). Автор проводит параллель между художником и шаманом, по верованиям, человеком, способным одновременно пребывать во всех трех мирах (подземном-нижнем; земном-средним; небесном-верхнем), быть проводником в миры духов и богов, своеобразным столпом, осью, на которую «нанизаны» все сферы материального и духовного бытия. Как художник является посредником между конечным человеком-зрителем и божественным (природным) материалом-абсолютом, творя художественное произведение, так и шаман находится на границе между миром земным и миром духов, помогая соблюдать баланс мироздания. Символика числа три в произведении «Три шамана» раскрывается как мироустройство, пришедшее сакральное знание из глубины веков от наших общих предков, а хранителями знаний были шаманы (Smoliak, 1991). Будучи одним из наиболее распространенных элементов мифопоэтической символики, круг заключает идею единства, бесконечности и законченности. Круг как форма изначально содержит пластическую идею, выраженную правильно кривой линией без начала и конца природного происхождения (териоморфные образы змеи или дракона, проглатывающих свой хвост). Круг ограничивает внутреннее конечное пространство, но круговое движение, образующее это пространство, потенциально бесконечно. Так, во многих этнических традициях космос представляется как шар (графически круг) (Chirkov, 2010).

Таким образом, символический статус произведения С.Е. Ануфриева «Три шамана» способен дополнить сформированное на иконическом статусе представление о космосе как трехчастном и трехуровневом мироустройстве, где центральной осью служит посредник (шаман, художник), с помощью техник и практик (в т. ч. панё) позволяющий оградить от бед и несчастий человека-зрителя. Пространственная трехчастная декоративная композиция «Три шамана» в чувственно явленной форме демонстрирует совершающийся здесь и сейчас охранительный обряд Вселенной, приглашая зрителя присоединиться к необычайно редкому явлению - групповому камланию шаманов. Эффект диалога с произведением, присутствия и сопричастности зрителя к камланию «Трех шаманов» усиливается, учитывая факт соразмерности человеческому росту высот объемной трехчастной композиции в условиях экспозиционного зала музея.

Итак, тема связи сибирского человека и сибирской природы вновь выступает центральной идеей произведения С.Е. Ануфриева, но в пространстве постсоветского периода она прочитана с точки зрения архаических культурных архетипов: обращение к древнему прошлому сибирской земли через символы древних культур. Вновь главным героем и образцом для подражания выступает человек обезличенный - вне этнических, религиозных и культурных различий, но с миссией восстановления и удержания единства разных миров, культур и времен.

\section{Выводы}

Исследование этнокультурной динамики Красноярского края позволило выделить три основных этапа: досоветский, советский и постсоветский. В творчестве красноярских художников досоветский период характерен этнографическим и документальным направлением. Художники обращаются к темам столкновения коренных народов с пришлыми людьми, а также 
к анализу природного колорита и характерным особенностям местных жителей вне зависимости от их этнической принадлежности. Советский этап продолжает линию этнокультурных исследований, смещая акцент на конкретную личность и ее связь с природой. Выстраивается образ нового советского человека, стремящегося не только покорить местную стихию, но и уподобиться ей. Художники постсоветского периода обращаются к архаике через символы древних культур, проживавших на территории Красноярского края. В целом можно проследить общую тему отношения человека и местной земли и трансформацию образа жителей этих территорий.

\section{Список литературы}

Василий Иванович Суриков. Письма. Воспоминания о художнике (1977). Ленинград, 381 с. Жуковский, В.И. (2011). Теория искусства. Санкт-Петербург, 496 с.

Лисовский, Н.В. (1974). Сибирский художник Д.И. Каратанов. Красноярск, 143 с.

Ломанова, Т.М. (2007). Художники земли Красноясрской: каталог. Красноярск, 259 с.

Ломанова, Т.М. (2015). Декоративно-прикладное искусство Красноярского края. Мир, преображенный руками мастеров. Красноярск, 318 с.

Лысенко, И.С. (2008). Специфика этнического состава населения Красноярского края конца XX - начала XXI века // Вестник НГУ. Серия: История, филология, 3, 175-182.

Малолетков, В.А. (2004). Три школы в декоративной керамике России 70-90-х годов ХХ века // Декоративное искусство и предметно-пространственная среда. Сборник научных трудов, 3, Москва, 16 с.

Мамышева, Е.П. (2018). Переселенцы и инородческое население в Енисейской губернии во второй половине XIX - начале XX вв. (на материалах Минусинского и Ачинского округов): проблема взаимоотношений // Genesis: исторические исследования, 11, 101-107.

Москалюк, М.В. (2010). Все, что в сердце: художники Красноярья вчера, сегодня, завтра. Красноярск, 288 с.

Москалюк, М.В., Знак, И. А., Ракова, В. Б. (2000). Юрий Ишханов: скульптура. Красноярск, 48 с.

Официальные электронные ресурсы Всероссийской переписи 2002 и 2010 годов, режим доступа: http://www.perepis2002.ru/index.html?id=11; http://www.perepis-2010.ru/

Официальный портал Красноярского края, режим доступа: http://www.krskstate.ru/kmns/kmns Ряннель, Т.В. (1948). Художник Каратанов. Красноярск, 23 с.

Сертакова, Е.А. (2014). Визуализация образа города и облика горожан в часовне Параскевы Пятницы в Красноярске // Урбанистика, 2, 50-64.

Смоляк, А.В. (1969). Этнографические данные об обрядах ложных погребений у народов Нижнего Амура // Сов. Археология, 3, 262-264.

Смоляк, А.В. (1991). Шаман: личность, функции, мировоззрение (народы Нижнего Амура). Москва, 280 с.

Строй, Л.Р. (2017). Творческое наследие художника Д.И. Каратанова // Исторические, философские, политические и юридические науки, культурология и искусствоведение. Вопросы теории и практики, Тамбов, 4(78), 192-195.

Тригалева, Н.В. Председатель регионального отделения. Ануфриев Сергей Евгеньевич. Сайт РАХУСДВ, режим доступа: http://www.rahusdv.ru/anufriev

Тугужекова, В.Н. (2017). 1917 год: национальный вопрос на юге Енисейской губернии // Вестник ХГУ им. Н.Ф. Катанова, 22, 82-84.

Худоногова, Е.Ю. (2001). Архаические фантазии Сергея Ануфриева // Палитра, Красноярск, 29 с. Чирков, В.Ф. (2010). Сергей Ануфриев. Точки соприкосновения. Красноярск, 95 с.

Чирков, В.Ф. (2010). Искусство Сергея Ануфриева // Сергей Ануфриев. Точки соприкосновения, 2. Чирков, В.Ф. (2018). ХІ Сибирские искусствоведческие чтения «Сибирский пейзаж: от топа к типу, от мотива к художественному образу» // Сборник материалов Всероссийской научно-

$$
-886-
$$


практической конференции в рамках Межрегиональной художественной выставки пейзажа «Родина-Сибирь», Красноярск, 223 с.

Шавлыгин, Д.О. (2020). Образ современника в творчестве красноярских скульпторов ХХ века // Изобразительное искусство Урала, Сибири и Дальнего Востока. Красноярск, 57-63.

Энциклопедия Красноярского края, режим доступа: http://my.krskstate.ru/docs/national/ natsionalnyy-sostav/

Этническая история народов Красноярского края: библиографический указатель. (2006). Красноярск, 202-204.

\section{References}

Amosova, M.A., Koptseva, N.P., Sitnikova, A.A., Seredkina, N.N., Zamaraeva, Y.S., Kistova, A.V., Reznikova, K.V., Kolesnik, M.A., Pimenova, N.N. (2019). Ethnocultural identity in the works of Krasnoyarsk artists. In Journal of Siberian Federal University. Humanities and Social Sciences, 12(8), 15241551.

Chirkov, V.F. (2010). Sergey Anufriev. Tochki soprikosnoveniia [Points of contact]. Krasnoyarsk. 95 p.

Chirkov, V.F. (2010). Iskusstvo Sergeia Anufrieva [Art by Sergei Anufriev]. In Sergej Anufriev. Tochki soprikosnoveniia [Sergey Anufriev. Points of contact], Krasnoyarsk, 2 p.

Chirkov, V.F. (2018). XI Sibirskie iskusstvovedcheskie chteniia «Sibirskij pejzazh: ot topa k tipu, ot motiva k khudozhestvennomu obrazu» [XI Siberian art history readings «Siberian landscape: from top to type, from motive to artistic image»]. In Sbornik materialov Vserossijskoj nauchno-prakticheskoj konferencii v ramkakh Mezhregional'noj khudozhestvennoj vystavki pejzazha «Rodina-Sibir'» [Collection of materials of the All-Russian scientific-practical conference in the framework of the Interregional art exhibition of landscape «Motherland-Siberia»]. Krasnoyarsk, 223 p.

Enciklopediia Krasnoiarskogo kraia [Encyclopedia of the Krasnoyarsk Territory] (2021). Available at: http://my.krskstate.ru/docs/national/natsionalnyy-sostav/

Etnicheskaia istoriia narodov Krasnoiarskogo kraia: bibliograficheskij ukazatel' [Ethnic history of the peoples of the Krasnoyarsk Territory: bibliographic index] (2006). Krasnoyarsk, 202-204.

Khudonogova, E. Iu. (2001). Arkhaicheskie fantazii Sergeia Anufrieva [Archaic fantasies of Sergei Anufriev]. Palitra, Krasnoyarsk, 29 p.

Kistova, A.V., Bulak, K.A., Pimenova, N.N., Shimanskaya, K.I., Pashova, E.V. (2020). The image of the Yenisei in the paintings of krasnoyarsk artists. In Journal of Siberian Federal University. Humanities and Social Sciences, 6 (13), 891-903.

Koptzeva, N.P., Reznikova, K.V. (2014). Three painting by Albert-Charles Lebourg and philosophical foundations of impressionism of the last third of the XIX. In Sententia. European Journal of Humanities and Social Sciences, 1, 78-90.

Koptseva, N.P., Reznikova, K.V., Razumovskaya, V.A. (2018). The construction of cultural and religious identities in the temple architecture. In Journal of Siberian Federal University. Humanities and Social Sciences, 11(7), 1021-1082.

Lisovskij, N.V. (1974). Sibirskij khudozhnik D.I. Karatanov [Siberian artist D. I. Karatanov]. Krasnoiarsk, $143 \mathrm{p}$.

Lomanova, T.M. (2007). Khudozhniki zemli Krasnoiarskoj: katalog [Artists of the land of Krasnoyarsk: catalog]. Krasnoyarsk, $295 \mathrm{p}$.

Lomanova, T.M. (2015). Dekorativno-prikladnoe iskusstvo Krasnoiarskogo kraia. Mir, preobrazhennyj rukami masterov [Decorative and applied art of the Krasnoyarsk Territory. A world transformed by the hands of masters]. Krasnoiarsk, $318 \mathrm{p}$.

Lysenko, I.S. (2008). Specifika etnicheskogo sostava naseleniia Krasnoiarskogo kraia konca KhKh nachala KhKhI veka [Specificity of the ethnic composition of the population of the Krasnoyarsk Territory in the late XX - early XXI century]. In Vestnik NGU. Seriia: Istoriia, filologiia [NSU Bulletin. Series: History, Philology], 3, 175-182. 
Maloletkov, V.A. (2004). Tri shkoly v dekorativnoj keramike Rossii 70-90-kh godov KhKh veka [Three schools in decorative ceramics in Russia in the 70-90s of the XX century]. In Dekorativnoe iskusstvo i predmetno-prostranstvennaia sreda. Sbornik nauchnykh trudov [Decorative arts and subject-spatial environment. Collection of scientific papers], 3, Moscow, 16 p.

Mamysheva, E.P. (2018). Pereselency i inorodcheskoe naselenie v Enisejskoj gubernii vo vtoroj polovine XIX - nachale XX vv. (na materialakh Minusinskogo i Achinskogo okrugov): problema vzaimootnoshenij [Settlers and non-Russians in the Yenisei province in the second half of the $19^{\text {th }}-$ early $20^{\text {th }}$ centuries. (based on materials from Minusinsky and Achinsky districts): the problem of relationships]. In Genesis: istoricheskie issledovaniia [Genesis: Historical Research], 11, 101-107.

Moskaliuk, M.V. (2010). Vse, chto v serdce: khudozhniki Krasnoiar'ia vchera, segodnia, zavtra [Everything in the heart: the artists of Krasnoyarsk yesterday, today, tomorrow]. Krasnoyarsk, $288 \mathrm{p}$.

Moskaliuk, M.V., Znak, I.A., Rakova, V.B. (2000). Iurij Ishkhanov: skul'ptura [Yuri Ishkhanov: sculpture]. Krasnoyarsk, 48 p.

Oficial'nye elektronnye resursy Vserossijskoj perepisi 2002 i 2010 godov [Official electronic resources of the All-Russian census of 2002 and 2010]. Available at: http://www.perepis2002.ru/index.html?id=11; http://www.perepis-2010.ru/

Oficial'nyj portal Krasnoiarskogo kraia [Official portal of the Krasnoyarsk Territory] (2021). Available at: http://www.krskstate.ru/kmns/kmns

Reznikova, K., Seredkina, N., Zamaraeva, J., Koptseva, N. (2017). The traditional economy of indigenous peoples of central Siberia (the case of the selkups). In International Journal of Economic Research, 14(15), 261-270.

Riannel', T.V. (1948). Khudozhnik Karatanov [Artist Karatanov]. Krasnoyarsk, 23 p.

Seredkina, N.N. (2011). The Visualization of Ethnic Theme in the Khakass Artists Paintings and Graphic Works of Art. In Journal of Siberian Federal University. Humanities \& Social Sciences, 8 (4), 1109-1126.

Seredkina, N.N., Kistova A. V., Pimenova N. N. (2019). «The Frieze of Life» by Edvard Munch: Philosophical and Art Analysis. In Journal of Siberian Federal University. Humanities \& Social Sciences, 7 (12), 1295-1315.

Sertakova, E.A. (2014). Vizualizatsiya obraza goroda i oblika gorozhan v chasovne Paraskevy Pyatnitsy v Krasnoyarske [Visualization of the image of the city and the appearance of citizens in the Paraskeva Pyatnitsa chapel in Krasnoyarsk]. In Urbanistika [Urban Studies], 2, 50-64.

Shavlygin, D.O. (2020). Obraz sovremennika v tvorchestve krasnoiarskikh skul'ptorov KhKh veka [The image of a contemporary in the works of Krasnoyarsk sculptors of the twentieth century]. In Izobrazitel'noe iskusstvo Urala, Sibiri i Dal'nego Vostoka [Fine arts of the Urals, Siberia and the Far East]. Krasnoyarsk, 57-63.

Sitnikova, A.A. (2014). The Concept of «North» in the Works by Rockwell Kent. In Journal of Siberian Federal University. Humanities \& Social Sciences, 8 (7), 1358-1380.

Smoliak, A.V. (1969). Etnograficheskie dannye ob obriadakh lozhnykh pogrebenij u narodov Nizhnego Amura [Ethnographic data on the rituals of false burials among the peoples of the Lower Amur]. In Sov. Arkheologiia [Sov. archeology], 3, 262-264.

Smoliak, A.V. (1991). Shaman: lichnost', funkcii, mirovozzrenie (narody Nizhnego Amura) [Shaman: personality, functions, worldview (peoples of the Lower Amur)]. Moscow, $280 \mathrm{p}$.

Stroj, L.R. (2017). Tvorcheskoe nasledie khudozhnika D. I. Karatanova [The creative heritage of the artist D.I. Karatanov]. In Istoricheskie, filosofskie, politicheskie i iuridicheskie nauki, kul'turologiia i iskusstvovedenie. Voprosy teorii i praktiki [Historical, philosophical, political and legal sciences, cultural studies and art history. Questions of theory and practice], Tambov, 4(78), 192-195.

Trigaleva, N. V. Predsedatel' regional'nogo otdeleniia. Anufriev Sergej Evgen'evich [Chairman of the regional office. Anufriev Sergey Evgenievich]. Website RAKhUSDV. Available at: http://www.rahusdv.ru/ anufriev 
Tuguzhekova, V.N. (2017). 1917 god: nacional'nyj vopros na iuge Enisejskoj gubernii [1917: the national question in the south of the Yenisei province]. In Vestnik KhGU im. N. F. Katanova [Bulletin of KSU named after N.F. Katanova], 22, 82-84.

Vasilij Ivanovich Surikov. Pis'ma. Vospominaniia o khudozhnike [Vasily Ivanovich Surikov. Letters. Memories of the artist] (1977). Leningrad, $381 \mathrm{p}$.

Zhukovsky, V.I. (2011). Teoriya iskusstva [Theory of art]. St. Petersburg, 496 p. 